\begin{tabular}{|c|c|c|c|c|c|c|}
\hline \multirow{4}{*}{ Impact Factor: } & ISRA (India) & $=3.117$ & SIS (USA) & $=0.912$ & ICV (Poland) & $=6.630$ \\
\hline & ISI (Dubai, UAE & $=0.829$ & РИНЦ (Russia) & $=0.156$ & PIF (India) & $=1.940$ \\
\hline & GIF (Australia) & $=0.564$ & ESJI (KZ) & $=5.015$ & IBI (India) & $=4.260$ \\
\hline & JIF & $=1.500$ & SJIF (Morocco) & $=5.667$ & & \\
\hline
\end{tabular}

SOI: $\underline{1.1 / \mathrm{TAS}} \quad$ DOI: $\underline{10.15863 / \mathrm{TAS}}$
International Scientific Journal
Theoretical \& Applied Science
$\begin{array}{ll}\text { p-ISSN: } 2308-4944 \text { (print) } \quad \text { e-ISSN: } 2409-0085 \text { (online) } \\ \text { Year: } 2018 \quad \text { Issue: } 12 \quad \text { volume: } 68 \\ \text { Published: } 25.12 .2018 \quad \underline{\text { http://T-Science.org }}\end{array}$

QR - Issue

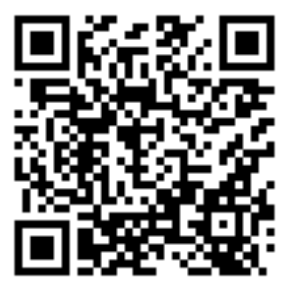

QR - Article

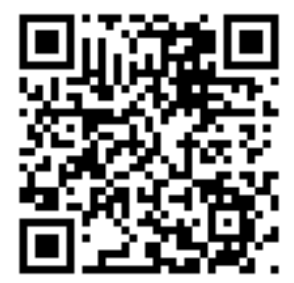

Jahongir Yakhshilikov

Samarkand State University, Samarkand, Uzbekistan

j_yahshilikov@hotmail.com

\title{
PROBLEMS OF KNOWLEDGE THROUGH CIVILIZATIONAL APPROACH AND PRINCIPLES OF CIVIL LAW. CASE OF UZBEKISTAN
}

\begin{abstract}
This paper makes investigations on civil law and its principles as whole. Moreover, the way of social life and problems of civilization are mentioned accordingly. Therefore, levels and tendencies of the principles that establish the essence of civil law are categorized. Moreover, current status quo of this feature was analyzed in case of Uzbekistan. Furthermore, policy and structure of country on law and philosophy have been learned from both theoretical and practical point of view. Research finalizes major outcomes and shortcomings of the topic to make better analyses further.
\end{abstract}

Key words: law, civil law, property, private law, public law, legal capacity, relevance, legal understanding, equality, justice and freedom.

Language: English

Citation: Yakhshilikov, J. (2018). Problems of knowledge through civilizational approach and principles of civil law. Case of Uzbekistan. ISJ Theoretical \& Applied Science, 12 (68), 224-233.

Soi: http://s-o-i.org/1.1/TAS-12-68-32 Doi: crossef https://dx.doi.org/10.15863/TAS.2018.12.68.32

\section{INTRODUCTION}

Social philosophy is a science fiction about the social laws and the driving forces of the existence and development of society. The philosophy of law is to study the legal norms of the legal entity, and the philosophy of civil law explores the general, including substance law, which is characteristic of civil law relations. But the objective laws, including the knowledge of social philosophy, the philosophy of philosophy and the philosophy of civil law, depend on the understanding of social phenomena. These objective laws are manifested and dominated by civil law relations.

The ignorance, ignorance and disregard of these processes in civil-law relations leads to the limitations of the science of the researcher»s thinking. So, the definition of social relations, including the principles of knowing civil-law relations, and the logical continuity of knowledge about it also depend on the social philosophical understanding. Hence, the substance of the know-how, which leads to the whole idea of understanding, is the basis which unites the idea of the beginning and the end. This logical process is also about knowing the principles of civil law. The point is that as the content of the principles is objective and knowledgeable, it is also dependent on philosophical concepts of civil law, including the process.

The dialectical cultural understanding of history and its ultimate goal - civilization changes in all social, including civil rights, are related to the cultural reality, which requires the definition of the methodological significance of the category of «culture».

«Culture» provides Latin «care», «processing» and «upbringing». In the agricultural sciences, the word «cultured rastenie», «cultivated plants», «cultivation», «processing», are used as whole. Thus, there are two occurrences of natural phenomena human events. This part of the event, in other words , nature is called «cultura». Maintenance is also a process of cultivating.

This is the essence of the concept of culture that is scientifically applied as a process. Therefore, S. Abdukholikov summarizes achievements in various cultural approaches: «Humanity used the concept of «cultura» to distinguish it from the natural things. Thus, culture is the entity that transforms and creates events by the human being and by the new quality, that is, the cultural existence. «10 Cultural beings are the basis and nucleus of the existence and 


\begin{tabular}{|c|c|c|c|c|c|c|}
\hline \multirow{4}{*}{ Impact Factor: } & ISRA (India) & $=3.117$ & SIS (USA) & $=0.912$ & ICV (Poland) & $=6.630$ \\
\hline & ISI (Dubai, UAE & $=0.829$ & РИНЦ (Russia) & $=0.156$ & PIF (India) & $=1.940$ \\
\hline & GIF (Australia) & $=0.564$ & ESJI (KZ) & $=\mathbf{5 . 0 1 5}$ & IBI (India) & $=4.260$ \\
\hline & JIF & $=1.500$ & SJIF (Morocco) & $=5.667$ & & \\
\hline
\end{tabular}

development of society. With this description, a new trend in understanding culture has begun. "Unlike nature,» says the authors community of one of the philosophical textbooks in Rostov-on-Don, «culture is both material and spiritual.

\section{THEORETICAL BACKGROUND}

Culture is a specially crafted, humane nature that meets all these needs. "As can be seen from this description, culture is unique. It does not happen without human beings. H.T. Odilkariev and Sh.F. The philosophers confirmed this philosophical idea and created a system called «cultural heritage» that embraces everything that was created during the era of «miraculous sophistication» of modern civilization, which is the primary source of material culture, from the "simple stone crusher» to modern miracles.

Hence, the development of the term «cultural entity» and its introduction into the scientific context can be considered as a new category of culture understanding. Of course, this is about the culture of society. The culture of society, that is, the cultural heritage of a single person - has a vast amount of human culture, which includes it. The culture of the person is the ability of the individual to know and use it.

According to book called "Cultural History and Its Problem" has been discovered that the major aspects of society - the spheres of social, political, legal, and spiritual life. On this way, ideas have been ignored but their cultural components are correlated according to the functional aspects of these cultural aspects the formation of a cultural entity, the formation of the attribute, the way of life, the central part, the essence of the social existence and the development of cultural existence. On the basis of these ideas, the essence of dialectical cultural understanding was discovered.

As cultural entities form the basis for the existence and development of society, human beings and its units are the elements of spiritual, material, political and legal culture of the society. These components are based on the social, spiritual, material and political life of the society. Thus, in the social philosophy based on dialectical cultural understanding, the idea that social beings is a constituent of society, in other words social life, and that its central part is a cultural entity.

In the scientific research, we see that this social philosophical principal idea and the corresponding correlation - functional and substanceal laws we have already pointed out. Professor Z.M.Islamov, a doctor of jurisprudence, observes these scientific journals and scientific journals: «... Materialist method of dialectics, that is, materialist understanding of history, including the law, was absolutely universal and one of the only correct methods. Understanding that Marxism - Leninism has come to an end in such a conception. In particular, any right was only limited to property. True, economic law represents economic relationships.

\section{METHODOLOGY}

Civil society in Uzbekistan has been primarily associated with mahallas, which are self-governing bodies. The mahalla system in Uzbekistan is an important institution of local self-governance, which plays a significant socioeconomic development role. The mahalla is a community-driven organization responsible for helping members of the community and other social work (conflict resolution, overall community upkeep, etc.). At the present time, the mahalla structure and functions are based on the law on Institutions of Self-Government of Citizens (the Mahalla Law of 1999). Civil society in Uzbekistan today is broader than the traditional mahalla system. It covers businesses, grassroots initiatives, government initiatives, and political parties, among others. Civil society began developing during 19911995. The Business Women Association of Uzbekistan, Tadbirkor Ayol (which has offices in Tashkent and each province), the Association of Pediatricians (Bukhara), Perzent (Nukus), the Association of Accountants and Auditors (Tashkent), the Female Resource Center (Tashkent), and Kridi (Tashkent) were among the first nongovernment organizations (NGOs) who formed in this period.

Right is a certain aspect of human relationships. They are objective. In fact, the majority of people are conscious, purposeful, ie cultural. It is also a cultural process that reflects these relationships at certain levels, based on a certain understanding. Therefore, the history, including dialectical cultural understanding of rights, is also being compiled. «

Thus, the idea that the central part of social life is a cultural one is the initial «springboard» of knowing its fundamental social philosophical principle of knowing the principles of civil law.

The above-mentioned ideas based on dialectical cultural perception of the idea of social philosophy have been developed in scientific literature and have been used in research subjects. In particular, the nature of the unifying and non-cultural aspects of the cultural aspects of each of the areas of social life has been defined. Not only that, but also their correlation functional integrity was highlighted. Social associations and their sides are cultural constituents of the material, spiritual and political-legal cultures, and constitute the basis of social life. «The core of society is the role of the components of cultural environment There are also a number of generally 


\begin{tabular}{|c|c|c|c|c|c|c|}
\hline \multirow{4}{*}{ Impact Factor: } & ISRA (India) & $=3.117$ & SIS (USA) & $=0.912$ & ICV (Poland) & $=6.630$ \\
\hline & ISI (Dubai, UAE & $=0.829$ & РИНЦ (Russia) & $=0.156$ & PIF (India) & $=1.940$ \\
\hline & GIF (Australia) & $=0.564$ & ESJI (KZ) & $=\mathbf{5 . 0 1 5}$ & IBI (India) & $=4.260$ \\
\hline & JIF & $=1.500$ & SJIF (Morocco) & $=5.667$ & & \\
\hline
\end{tabular}

accepted social laws correlation - functional laws. These laws indicate the place and functional status of civil rights in the social life. In the case of civil rights, the principles of civil law are formed.

\section{ASPECTS OF CIVIL SOCIETY}

One of the four main components of society is the social sphere of life and their social-class, demographic, territorial division, everyday life, health, sports and communal systems. For jobs and services, they are available in all areas of society. If pets, houses, clothes, food are not included in the system of exchanges, they will belong to the social sphere of society, in particular the system of living.
A major part of the social life of society is the social principle of law in relation to social life and its cultural components, in the functional status of the individual and its units. This is called law of the role of the subject in the law. This is a common law of publicity in the form of the civil law definition of the civil law and the law of the subjects of civil rights. Privileges, privacy, honor, privacy, occupational prestige, privacy, personal secrets, freedom of movement, residence and residence, and other personal property rights of citizens, together with legal entities, the attributes of the subjects of civil rights and are in the system of the social law of the society.

In broader terms, civil society in Uzbekistan today is represented by the following types of organizations (Figure 1).

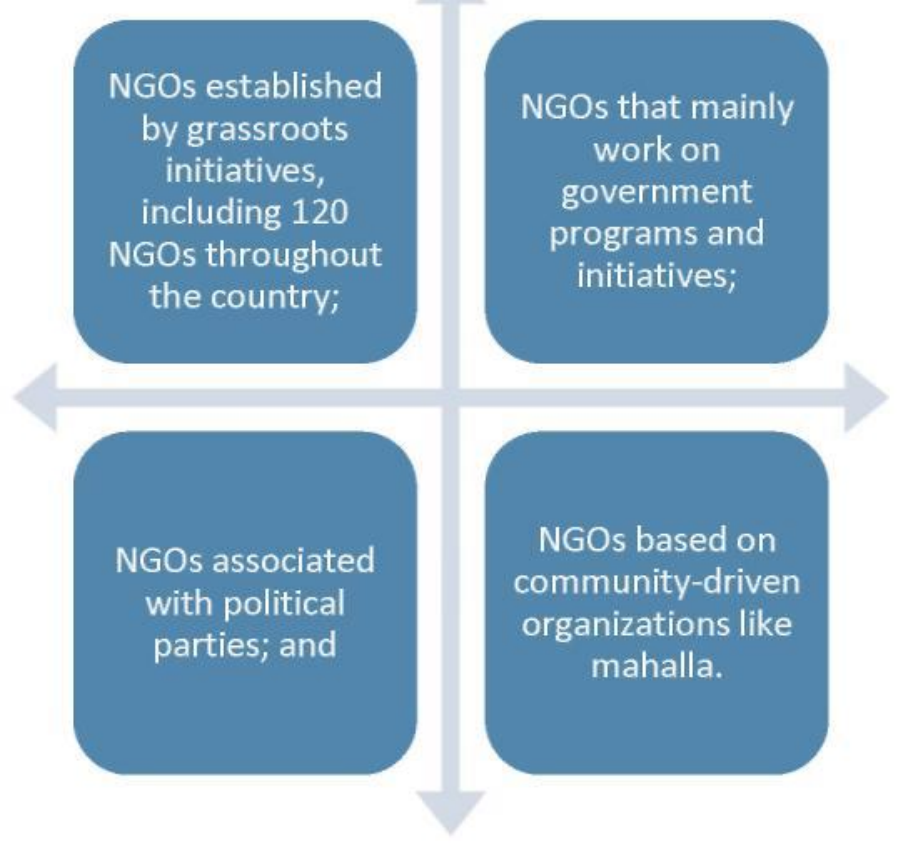

Figure 1. Types of civil society in Uzbekistan

The Social Structure Law is, firstly, the subject, the creator and the transporter, and secondly, in the form of mobility, that is, in the history of the people and the role of a person. In the civil law, the principles of personal non-material rights, including the genesis of the principle of personal inviolability, are derived from the social sphere of the society, and in the system of social law of society.

The Law "On Non-Government NonCommercial Organizations," which was passed on 14
April 1999, governs NGO operations. The public actively discussed the draft law. In addition to this law, there are several other regulatory documents, such as the Resolution "On Measures for Supporting the Development of Institutions of Civil Society" and "Regulations on the Procedure for Placing Social Orders among NGOs and Other Institutions of Civil Society." Legal Framework for activities is included from major features and rules as completely (Figure 2). 


\begin{tabular}{lllllll} 
& ISRA (India) & $=\mathbf{3 . 1 1 7}$ & SIS (USA) & $=\mathbf{0 . 9 1 2}$ & ICV (Poland) & $=\mathbf{6 . 6 3 0}$ \\
Impact Factor: & ISI (Dubai, UAE) $=\mathbf{0 . 8 2 9}$ & PUHL (Russia) $=\mathbf{0 . 1 5 6}$ & PIF (India) & $=\mathbf{1 . 9 4 0}$ \\
& GIF (Australia) & $=\mathbf{0 . 5 6 4}$ & ESJI (KZ) & $=\mathbf{5 . 0 1 5}$ & IBI (India) & $\mathbf{4 . 2 6 0}$ \\
& JIF & $\mathbf{1 . 5 0 0}$ & SJIF (Morocco) $=\mathbf{5 . 6 6 7}$ & & \\
\hline
\end{tabular}

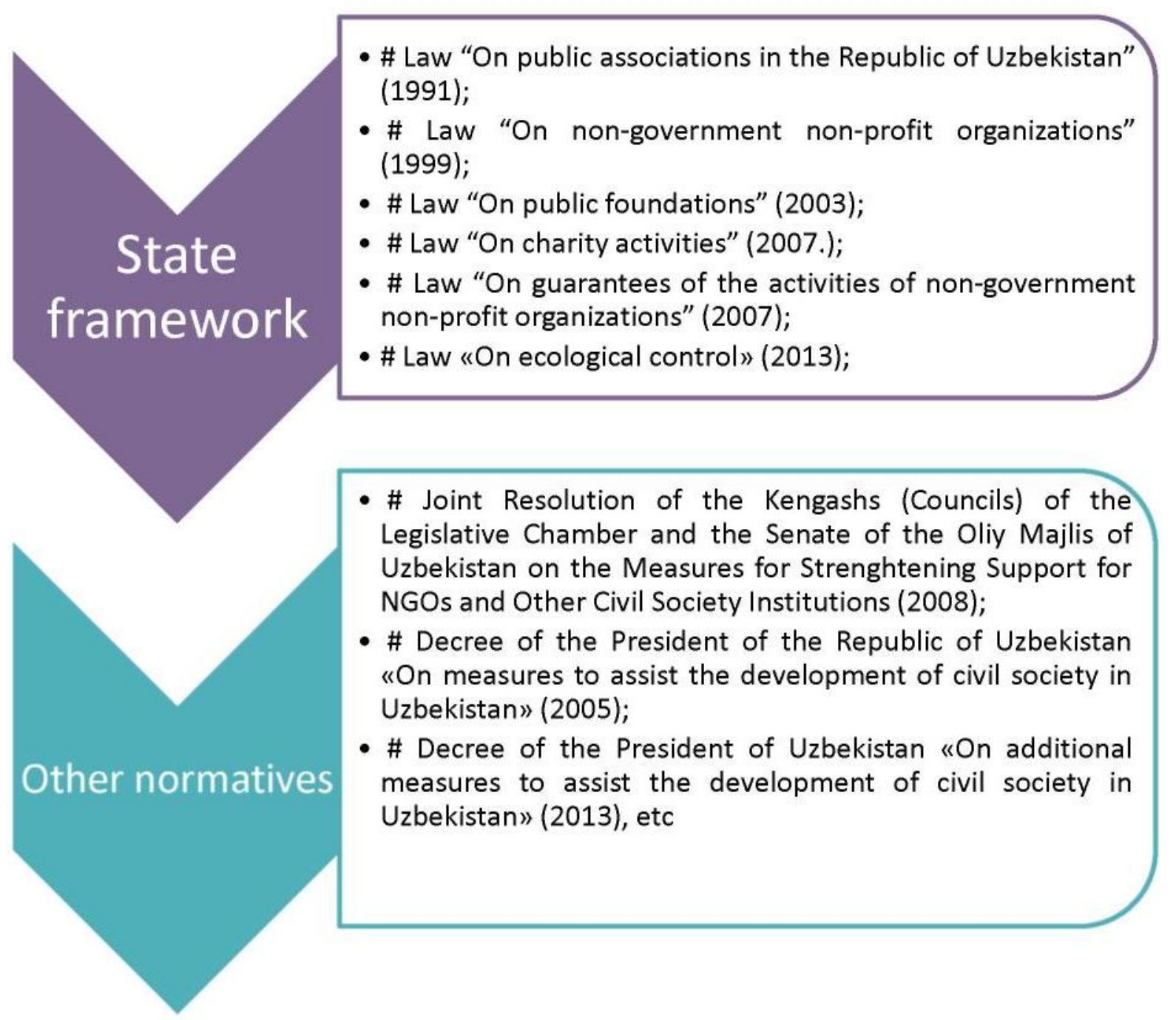

Figure 2. Legal framework of activities

As we have already mentioned, the norms reflecting the role of the definition of the subjects of civil rights in the civil-life relations in the sphere of social life, in particular, the formalization of the norms reflecting the personal non-material rights remain open.

The main social law in historical materialism was that the law of production of material things was a law of determining the other areas of social life and their development. However, the facts show that the basic principle of social law is general law. Indeed, the nucleus of the society - cultural entities change as the subjects change. As the substance changes, the cultural reality varies, and the changing of the cultural reality varies.

These changes are mostly evolutionary. We just use the word «revolutionary» to refer to its immediate moments. So, if there are qualitative changes in the subjects of civil rights, changes in the relationships of the civil law will also take place. Eventually, Roman civil law in ancient Rome conformed to the needs of the people at the time, and today it does not meet the interests of the citizens of the Republic of Uzbekistan.

These changes imply the improvement of the civil rights regulating. This requirement is governed by the principles of civil law. Another important part of society is the material life of society. The core of material life, that is, its cultivated part, consists of material culture and economy. The economic life of the society is based on the culture of the economy. In addition to the economic culture of the society, there is also a side-by-side ecological entity. Ecosystems are based on the well-being of society.

The economic culture of society is a combination of technological and economic culture of society. One of the objects of civil law is the economic culture of domestic animals, households, production tools, equipment, clothing, foodstuffs. If pets, clothes, food 


\begin{tabular}{|c|c|c|c|c|c|c|}
\hline \multirow{4}{*}{ Impact Factor: } & ISRA (India) & $=3.117$ & SIS (USA) & $=0.912$ & ICV (Poland) & $=6.630$ \\
\hline & ISI (Dubai, UAE & $=0.829$ & РИНЦ (Russia) & $=0.156$ & PIF (India) & $=1.940$ \\
\hline & GIF (Australia) & $=0.564$ & ESJI (KZ) & $=\mathbf{5 . 0 1 5}$ & IBI (India) & $=4.260$ \\
\hline & JIF & $=1.500$ & SJIF (Morocco) & $=5.667$ & & \\
\hline
\end{tabular}

are in the system of exchanges, they are part of the community»s economic life. If technological culture forms the basis of technological life (eg, wheat or cotton-growing), then the economic life of the society is based on the economic culture of society. Economic relations, property, exchange, distribution and consumption are the major part of society»s economic culture. The need to regulate this relationship has led to the emergence of the principles of civil and economic rights and their principles. In short, material culture is a complicated dialectical structure that is required by social life spaces and their cultural parts and, therefore, has the function of material basis upon them. The method of producing material benefits is based on this system of law. The basic object of civil law is the legal regulation of property relations in the system of material culture.

A part of the community»s political culture is the basic part of society»s cultivation, which has been devised to identify the community. It consists of political actors, political consciousness, knowledge, creativity, norms, institutions, political activities. The inner nature of all the spheres of social life requires the rule. So the basis for the management is objective. The central authority in the political culture of society is the power of the state.

Since the political culture of a society is a part of the political life, its core is the basis of its definition. Governance is required in all areas of public life. Therefore, the political culture of the society is governed by the rule of law in other areas of society and their cultural components. Legal law on civil law is in the same correlation - functional system of law. The first part of state power is the main creator of the legislative power. In addition, it guarantees the human rights protection at the outset. That is why legal life is aligned with political life.

Human and its units operate on all aspects of social life while acting ontologically and functionally as subjects of all aspects of social life. Civil rights are also examples of this. If social relations, including the necessity to guarantee the equality of justice, justice and freedom in civil law relations, are legal. It is the duty of the legislature to reflect them in the law. Guaranteeing them is one of the functions of the authorities.

Hence, the fact that the civil law principles are based on the private law system is inextricably linked with the government and its responsibilities. In summary, the legal culture of society is a part of the legality of social relations, which forms the core of the legal life of a country. It also acts as a correlativefunctional law that regulates the law of regulation of social life and their cultural components. Thus, the norms and principles of civil law are also legal cultural events. They will also be subject to submission to the whole system of legal culture.

It is also thought that the spiritual culture of society is the basis of spiritual life if we apply the principle that the cultural heritage of society is the basis of social existence. In the center of spirituality, the process is the process of perception in the human brain. The sphere of spiritual life consists of the specific lifestyle of society, its moral life, its aesthetic life and scientific life, its religious life, educational and media systems.

Their roots include cultures of ethical culture, aesthetic culture, science, religion, education, and the media system. Spiritual culture is one of them. Ownership relationships of civil law, next objects results of intellectual activity - inventions, industrial honors, science, art and other creative products, intellectual property are in the same system of spiritual culture. In addition, personal relationships that are not bound by civil law are also part of the spiritual culture.

\section{PRINCIPLES OF CIVIL SOCIETY}

Spiritual culture as a correlation - functional law of society serves as a moral basis for social life and its cultural aspects, including the law of gnoséological foundations. The society has no place in its relationship, including civil-law relations, through the consciousness of a human being, through the principle of spirituality. This fundamental principle of civil law is based on civil law, in particular through the principles of civil law. It is objectively conditioned that all spheres of social life, in the form of ideas of consciousness and general spirituality, are in the form of the principles of law. And when it is contracted it is necessary (Graph 3).

Thus, there are four correlative-functional laws of the society, which have parallel power and turn around the law of social law. In this regard, we want to express some points about the law of one of the laws taught in the historical materalism - the rule of law of the economic base. We have seen above that the right or the rule of law is objectively found in humans and in things and relationships they have created. For example, the age-related change in the ability of the citizen»s rights to change. And this is natural, as is the basis of civil law norms. As we have already mentioned above, basically, the use of the principle only in economic terms is a limited understanding. All aspects of some social life are social. material, moral, political and legal life.

The skill is meant to be built on. When we take them as objective processes, they are basically used and the form works as a form. Legal principles are based on a range of bases and frames that define and follow the rule.

The experience in Uzbekistan demonstrates that the new politics of civil society can be hacked to justify the continuation of the arbitrary control of administrators who are no accountable to citizens. Plainly, calls for 


\begin{tabular}{|c|c|c|c|c|c|c|}
\hline \multirow{4}{*}{ Impact Factor: } & ISRA (India) & $=3.117$ & SIS (USA) & $=0.912$ & ICV (Poland) & $=6.630$ \\
\hline & ISI (Dubai, UAE & $=0.829$ & РИНЦ (Russia) & $=0.156$ & PIF (India) & $=1.940$ \\
\hline & GIF (Australia) & $=0.564$ & ESJI (KZ) & $=5.015$ & IBI (India) & $=4.260$ \\
\hline & JIF & $=1.500$ & SJIF (Morocco) & $=5.667$ & & \\
\hline
\end{tabular}

civil society can be useful in containing or hampering opposition. Post-Soviet administrators» discourse on the mahalla as a foundation of civil society in
Uzbekistan is transparent as an expression of a desire to maintain control and voluntary subjection of citizens under the reorganising administration.

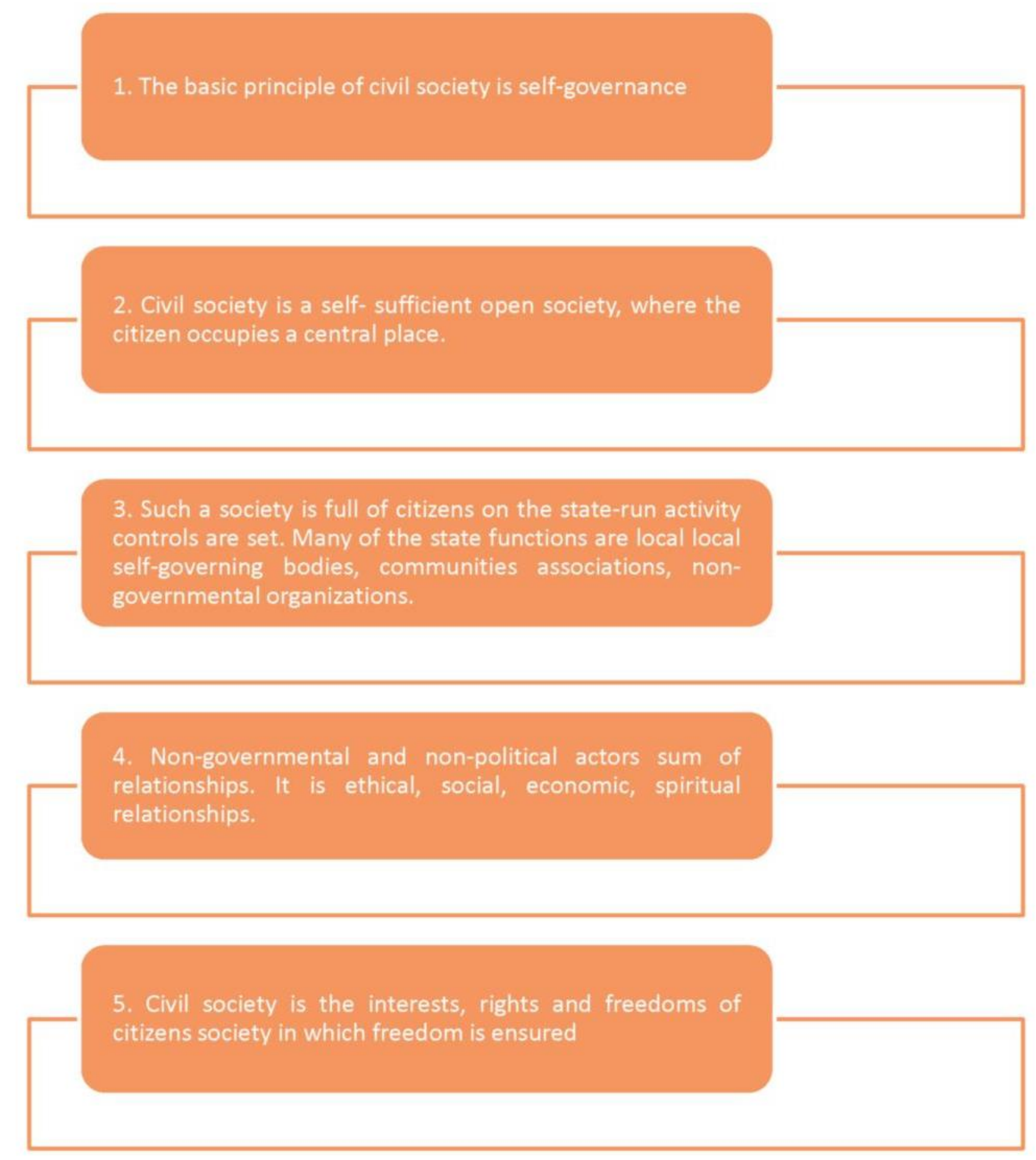

Graph 3. Features of civil society in Uzbekistan

The politics of «constructing» or «fostering» a civil society, played by both actors and researchers in civil society alike, irrespective of their original intentions, should be cautioned and reexamined, because «civil society» could be used to cover up the nature of underlying power relations and to acknowledge, either implicitly or explicitly, the necessity of interventionist administrative control 


\begin{tabular}{|c|c|c|c|c|c|c|}
\hline \multirow{4}{*}{ Impact Factor: } & ISRA (India) & $=3.117$ & SIS (USA) & $=0.912$ & ICV (Poland) & $=6.630$ \\
\hline & ISI (Dubai, UAE & $=0.829$ & РИНЦ (Russia) & $=0.156$ & PIF (India) & $=1.940$ \\
\hline & GIF (Australia) & $=0.564$ & ESJI (KZ) & $=5.015$ & IBI (India) & $=4.260$ \\
\hline & JIF & $=1.500$ & SJIF (Morocco) & $=5.667$ & & \\
\hline
\end{tabular}

from above. Endogenous formation of responsive institutions that guarantee the rights of the citizenry, such as independent political parties, fair and functioning judiciary institutions, free and professional media, and a truly open market economy, is a long and arduous process. However, only through such a formation of stable democracy can a democratic civil society be achieved in the region. After all, individual rights are only effectively protected by one»s status as a citizen of a democratic state. Walzer»s suggestion that «only a democratic state can create a democratic civil society, only a democratic civil society can sustain a democratic state» 103 sounds all the more true in the environment surrounding Uzbekistan.

The third step in the emergence of social philosophy, based on dialectical cultural understanding, was the doctrine of civilizations. The founder of the Republic of Uzbekistan I.A.Karimov used civilization in the meaning of the country: «In our country, where there is a great cultural heritage, many independent civilizations have their values transferred from generation to generation and the continuity of spiritual and cultural values.» F.Brodel also suggested this idea. "If we look at France in its most common chronological framework,» he says, «it»s different and similar, sometimes peaceful, spacious, split, split, as well as frustrating, fierce, successful, France, in its entirety, gradually replacing each other. " Further divisions of interests triggered by privatisation might engender internal differences among administrators in preference to executing policies. These differences, in turn, might engender personnel changes in administration, but this too will not necessarily induce democratisation. In Uzbekistan, it is difficult to imagine in the near future that the civil public will transform itself into the political public, exercising its rights to dismiss regimes that failed to respond to the people»s aspirations. People tend to regard politics as something to avoid, as an ethically corrupt business.
Thus, in civilization, citizens and states require each other. This is happening in a particular historical space and time (Graph 4).

This phenomenon is expressed through the concept of the country. Because both the state and the citizenship are in a particular country. However, the word of the country has little emphasis on social philosophy. That is why «the country,» says V.P Pankov, «the state of the ethnocultural unity of people, as long as the stage of dynamic advancement has been realized, no matter how much the social space of a state that regulates through the» civil society-state «relationship, has not been reflected in the existence of a social - philosophical conception of apparatus. "One of our goals is to justify the legitimacy of civil law and its principles that relate to civilizations. So citizens» rights and their principles have changed in every country. Thus, civilization is a country with its own citizens and state. Each country, as a specific civilization, brings norms, based on certain principles of civil law, and establishes and guarantees the authority of the state. This is how civilizational approach to civil law and its principles are taken

Thus, every civilization, as a whole, is a selfdeveloped country, as a community, self-evolving on the basis of its cultural dimension, its need, does not mean that civilizations do not mean «cultures» or integration. Citizens of each country have regular contacts with other citizens of the country. This process leads to the integration of positive and positive aspects of conflict into cultures.

It is a part of the common law of the common culture of society, which is a part of the legal culture of society, as well as civil law and its principles. The Code of Civil Law of the Republic of Uzbekistan and the relevant laws and regulations of the Republic of Uzbekistan are being developed with the comparative analysis of the legal systems of developed countries. 


\begin{tabular}{|c|c|c|c|c|c|c|}
\hline \multirow{4}{*}{ Impact Factor: } & ISRA (India) & $=3.117$ & SIS (USA) & $=0.912$ & ICV (Poland) & $=6.630$ \\
\hline & ISI (Dubai, UAE & $=0.829$ & РИНЦ (Russia) & $=0.156$ & PIF (India) & $=1.940$ \\
\hline & GIF (Australia) & $=0.564$ & ESJI (KZ) & $=5.015$ & IBI (India) & $=4.260$ \\
\hline & JIF & $=1.500$ & SJIF (Morocco) & $=5.667$ & & \\
\hline
\end{tabular}

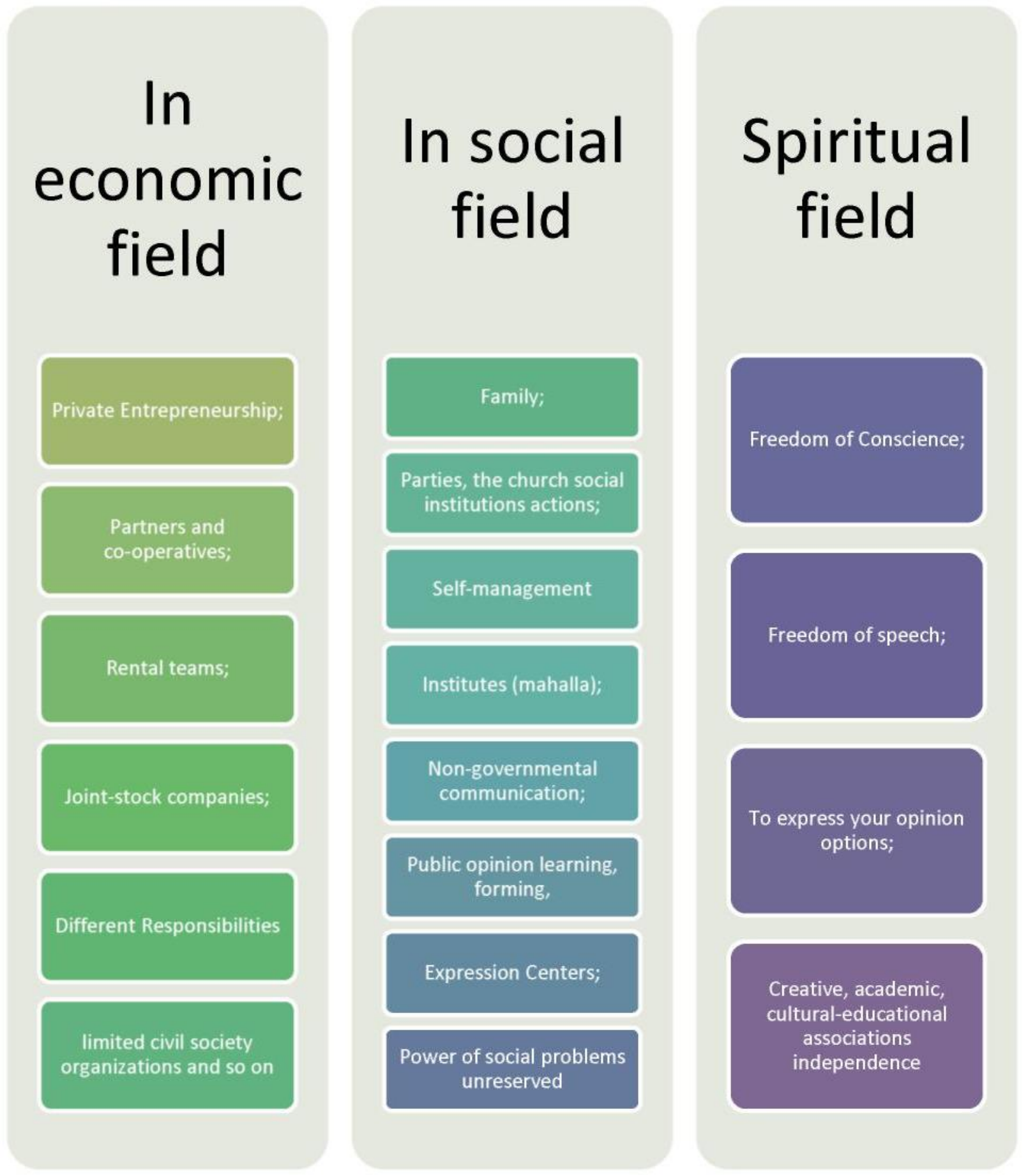

Graph 4. Civil society structure

\section{CONCLUSIONS}

From a legitimate point of view, human rights include the rights of individual rights and freedoms, political, economic, and social rights. Human rights include a broader sense, as well as the obligations of citizens. The main content of human rights is the right to citizenship, with the rights of nationals of a nationality and without citizenship. The Civil Code is a set of legal norms that regulates and strengthens property and personal non-personal relationships between businesses that are legally equal. In sum, all three signs of equality, justice, and freedom are manifested in the civil law. In civil law, voluntary equality of participants is the primary one. That is why this is a private law system. At the same time, the 


\begin{tabular}{|c|c|c|c|c|c|c|}
\hline \multirow{4}{*}{ Impact Factor: } & ISRA (India) & $=3.117$ & SIS (USA) & $=0.912$ & ICV (Poland) & $=6.630$ \\
\hline & ISI (Dubai, UAE & $=0.829$ & РИНЦ (Russia) & $=0.156$ & PIF (India) & $=1.940$ \\
\hline & GIF (Australia) & $=0.564$ & ESJI (KZ) & $=\mathbf{5 . 0 1 5}$ & IBI (India) & $=4.260$ \\
\hline & JIF & $=1.500$ & SJIF (Morocco) & $=5.667$ & & \\
\hline
\end{tabular}

participants will voluntarily settle their lives on the basis of their own interests. Therefore, voluntary equality constitutes the source of the root of all the principles of civil law, the source and basis of the ritual. Equality in this order constitutes the essence of civil law, which determines the direction of civil law principles.

On the whole, analysis of inquiries proves an awareness of citizens about the existing legal mechanisms for protection of their rights, ability and readiness to assert them under the law that, conversely, is an indicator of relatively high level of legal culture of the population. In the meantime, considering analysis of the monitoring results it is feasible under practical implementation of the Concept to speed up development and adoption of National Program on the rising ofthe legal culture in the society aimed at the cardinal improvement of legal education. Thereat, this program should foresee the practical measures on the strengthening of the interaction of the civil society institutes with public bodies in securing citizens» rights, rising of their legal culture and social-political activity, improving efficiency and practical performance of their activities in this sphere

Work on this paper has allowed to fully assessing the state of civil society in Uzbekistan, revealing untapped reserves and designating tasks in strengthening of role and significance of civil society in the deepening of democratic reforms. The results of monitoring carried out by the IIMFCS witness strengthening of the role of civil society institutes in the implementation of socially important tasks on the ground, in protection of the rights, liberties and legal interests of people.

In particular, activity of the representatives of NGOs and mass media in development and discussion of the proposals on improvement of law was recorded. Quality changes in activity of the mass media are observed, their role in detection and coverage of urgent problems of the local population is increasing.

Outcomes of surveys also reflect the socialeconomic activity and legal culture of citizens of the country. This being stated, the authors can finish this report by a quotation from the President of Uzbekistan Islam Karimov»s speech: «It is arguable that we have achieved the main thing - reformation and democratization process of the countr $y$ has at tained an irrevocable and consistent character, people is changing, their political and civic engagement, their consciousness, interconnectedness to everything happening around them, and finally, their faith in the country»s future are growing».

\section{References:}

1. Abdul Rashid, Zabid, Sambasivan, Murali, \& Johari, Juliana (2003). The influence of corporate culture and organizational commitment on performance. Journal of management development, 22(8), 708-728.

2. Ayanda, Adebayo Maruf, Lawal, Oloyede Raheem, \& Ben-Bernard, Pun (2014). Effects of human resource management practices on financial performance of banks. Transnational Journal of Science and Technology, 4(2).

3. Bhatti, Komal Khalid, \& Qureshi, Tahir Masood (2007). The impact of employee participation on job satisfaction, employee commitment, and employee productivity. International Review of Business Research Papers, 3(2), 54-68.

4. Brewster, Chris, \& Mayrhofer, Wolfgang. (2012). Handbook of research on comparative human resource management. Edward Elgar Publishing,

5. Budhwar, Pawan S, Chand, Mohinder, \& Katou, Anastasia A. (2007). The impact of HRM practices on organizational performance in the Indian hotel industry. Employee Relations, 29(6), 576-594.
6. Cohen, Jacob, Cohen, Patricia, West, Stephen G, \& Aiken, Leona S. (2013). Applied multiple regression/correlation analysis for the behavioral sciences. Routledge.

7. Deephouse, David L., Newburry, William, \& Soleimani, Abrahim (2016). The effects of institutional development and national culture on cross-national differences in corporate reputation. Journal of World Business, 51(3), 463-473.

8. Ferner, Anthony, Almond, Phil, \& Colling, Trevor (2005). Institutional theory and the crossnational transfer of employment policy: The case of «workforce diversity»in US multinationals. Journal of International Business Studies, 36(3), 304-321.

9. Gabriel, J. M. O., Gabriel, L. J. O. , \& Nwaeke, L. I. (2015). Reappraising Human Resource Management Practices as Predictor of Employees» Performance in the Nigerian Banking Industry. Current Evidence. Nature, 7(24).

10. Gabrielsson, Peter, Gabrielsson, Mika, \& Seppälä, Tomi (2012). Marketing strategies for 


\begin{tabular}{llllll} 
& ISRA (India) $=\mathbf{3 . 1 1 7}$ & SIS (USA) $=\mathbf{0 . 9 1 2}$ & ICV (Poland) & $=\mathbf{6 . 6 3 0}$ \\
Impact Factor: & ISI (Dubai, UAE) $=\mathbf{0 . 8 2 9}$ & PUHIL (Russia) $=\mathbf{0 . 1 5 6}$ & PIF (India) & $=\mathbf{1 . 9 4 0}$ \\
& GIF (Australia) $=\mathbf{0 . 5 6 4}$ & ESJI (KZ) & $\mathbf{5 . 0 1 5}$ & IBI (India) & $\mathbf{4 . 2 6 0}$ \\
& JIF & $\mathbf{1 1 . 5 0 0}$ & SJIF (Morocco) $=\mathbf{5 . 6 6 7}$ & & \\
\hline
\end{tabular}

foreign expansion of companies originating in small and open economies: the consequences of strategic fit and performance. Journal of International Marketing, 20(2), 25-48

11. Gelade, Garry A., \& Ivery, Mark (2003). The impact of human resource management and work climate on organizational performance. Personnel Psychology, 56(2), 383404.

12. Guest, David E. (1997). Human resource management and performance: a review and research agenda. International journal of human resource management, 8(3), 263-276.

13. Hogan, Suellen J, \& Coote, Leonard V. (2014). Organizational culture, innovation, and performance: A test of Schein»s model. Journal of Business Research, 67(8), 1609-1621.

14. Ibreck, Rachel (2013). International Constructions of National Memories: The Aims and Effects of Foreign Donors» Support for Genocide Remembrance in Rwanda. Journal of Intervention and Statebuilding, 7(2), 149-169.

15. Jiang, Jane Yan, \& Liu, Chi-Wei. (2015). Highperformance work systems and organizational effectiveness: The mediating role of social capital. Human Resource Management Review, 25(1), 126-137.

16. Karatepe, Osman M. (2013). High-performance work practices and hotel employee performance: The mediation of work engagement. International Journal of Hospitality Management, 32, 132-140.

17. Kearney, Eric, Gebert, Diether, \& Voelpel, Sven C. (2009). When and how diversity benefits teams: The importance of team members» need for cognition. Academy of Management Journal, 52(3), 581-598.

18. Kline, Rex B. (2015). The mediation myth. Basic and Applied Social Psychology, 37(4), 202-213.

19. Knight, Gary. (2000). Entrepreneurship and marketing strategy: The SME under globalization. Journal of International Marketing, 8(2), 12-32.

20. Laurent, Andre (1986). The cross-cultural puzzle of international human resource management. Human resource management, 25(1), 91-102.

21. Mobärg, Mats (2016). A proposed method of clarifying the meaning of contentious politicalcultural words: The case of country and nation. Nordic Journal of English Studies, 15(2), 6277.

22. Naranjo-Valencia, Julia C, Jiménez-Jiménez, Daniel, \& Sanz-Valle, Raquel. (2016). Studying the links between organizational culture, innovation, and performance in Spanish companies. Revista Latinoamericana de Psicología, 48(1), 30-41.

23. Purpora, Christina, \& Blegen, Mary A. (2015). Job satisfaction and horizontal violence in hospital staff registered nurses: the mediating role of peer relationships. Journal of clinical nursing, 24(15-16), 2286-2294.

24. Rabl, Tanja, Jayasinghe, Mevan, Gerhart, Barry, \& Kühlmann, Torsten M. (2014). A metaanalysis of country differences in the highperformance work system-business performance relationship: The roles of national culture and managerial discretion. Journal of Applied Psychology, 99(6), 1011.

25. Ramdani, Boumediene, Mellahi, Kamel, Guermat, Cherif, \& Kechad, Rabah. (2014). The efficacy of high-performance work practices in the Middle East: Evidence from Algerian firms. The International Journal of Human Resource Management, 25(2), 252-275. 